\title{
Lexical borrowing by Khoekhoegowab from Cape Dutch and Afrikaans
}

\author{
W.H.G. Haacke \\ Research Associate, Department of General Linguistics, Stellenbosch University \\ Email:whaacke@gmail.com
}

\begin{abstract}
The present article instantiates types of lexical borrowing from Afrikaans and Dutch in Namibian Khoekhoegowab (also known as "Nama"/"Damara"), but occasionally also refers to borrowings in the opposite direction. Where evidence allows, loans are traced back beyond Afrikaans to the era of Cape Dutch and contemporary interethnic contacts. Various categories ranging from adoptions to phonologically integrated loans, hybrids and calques are presented and, where possible, historical inferences are offered. The high degree of translational equivalence between Khoekhoe serial verbs and Afrikaans compound verbs leads to the consideration of some grammatical aspects including replication and relexification. Finally, reference is made to a parallel between Afrikaans and "Khoekhoe Afrikaans" syntax pointed out by den Besten (2013): Afrikaans circumlocutions like ek / sy wat Anna is (Khoekhoe: Anna.ta / Anna.s) are literal equivalents of the underlying phrasal structures of Khoekhoe surface nouns \#STEM.PGN\# in first, second or third person, as accounted for by the "desentential hypothesis" (Haacke 2006).
\end{abstract}

Keywords: kinship terms, phonological nativisation, epenthesis, hybrids, calques

\section{Introduction}

The influence of Cape Khoe on Cape Dutch and early Afrikaans has received recurrent attention as far as syntactic issues are concerned, particularly by Hans den Besten (cf. his list of publications in this volume). The Etimologiewoordeboek van Afrikaans (with supplement) suggests a (possible) "Khoi" etymology for some 66 Afrikaans entries. ${ }^{1}$ As the influence of Khoe on Cape Dutch and early Afrikaans has been covered fairly comprehensively, the present article will concentrate predominantly but not exclusively on loans from Afrikaans and Dutch in Khoekhoegowab ${ }^{2}$ as currently spoken in Namibia. It is not the intention of this

\footnotetext{
${ }^{1}$ I am indebted to Dr Willem F. Botha, Editor-in-Chief of the WAT project, for providing me with access to electronic extracts from the WAT database, and to Ms Tanja Harteveld for supplying the data files and handling personal communication. I am also grateful to Dr Herman Beyer for some valuable comments on a previous draft.

${ }^{2}$ Khoekhoegowab, literally "Khoekhoe-language", is the original glossonym for what had become known as "Nama/Damara" during the latter half of the $20^{\text {th }}$ century. The name Khoekhoegowab was, after Namibia's attainment of independence, officially reintroduced as the name for the language spoken by not only Nama but also Damara and Haillom. Cf. Haacke (2011) on how the glossonym Khoekhoegowab was gradually displaced
} 
article to contribute to the theoretical aspects of loan phenomena. Rather, the intention is to catalogue instantiation of mainly Dutch and Afrikaans interference with Khoe, and also some instances in the opposite direction. Any reference to Dutch here should be understood to be nonspecific concerning the degree of transition of original Dutch to Cape Dutch.

The data are selectively drawn from the dictionary of Haacke and Eiseb (2002), which marks some 330 Khoekhoe entries as loans from Afrikaans or Dutch. As this dictionary records $20^{\text {th }}$ century Khoekhoegowab as spoken in Namibia, there inevitably exists a disparity between the contemporary situation in this country, on the one hand, and the interaction of substrate Cape Khoe (and other Khoe ${ }^{3}$ lects) and Cape Dutch in previous centuries in South Africa, on the other. Hence it is difficult in most instances to detect which loans date back to early language contact in the Cape and which to later contact between modern Afrikaans and Khoekhoe in Namibia. Certain early loans from Dutch can be detected, however, through the survival of suffixes like the Dutch plural -en in Khoekhoe words, as will be elaborated on in the following section.

Before types of loans are discussed, some brief information on certain aspects of Khoekhoe nativisation may be helpful. While phonological adaptation will be discussed further on, a word on gender assignment to Khoekhoe nouns is opportune, especially since most loanwords tend to be nouns, being names for items that came to be known through cultural contact. Khoekhoe assigns gender to nouns. It is indicated by means of postclitic Person-GenderNumber (PGN) markers that are attached to noun stems; in the third person singular:

$s$ for feminine

$b$ for masculine (after final vowels, or a fully assimilated consonant $+i$ after stemfinal consonants) $-i$ for neuter

$$
\begin{array}{ll}
\text { e.g. khoe }+\boldsymbol{s} & \begin{array}{l}
\text { 'person' }+s=\text { 'woman' } \\
\text { e.g. khoe }+\boldsymbol{b}
\end{array} \\
\begin{array}{ll}
\text { 'person' }+b=\text { 'man', } \\
x a m+m i=\text { 'male lion' }
\end{array} \\
\text { e.g. khoe }+-\boldsymbol{i} & \begin{array}{l}
\text { 'person' }+-i=\text { 'person, } \\
\text { someone' }
\end{array}
\end{array}
$$

For inanimates, masculine gender is assigned to larger and elongated objects, while feminine gender is assigned to smaller, softer, roundish objects, e.g. !ā.b ('river') but !ā.s ('settlement, village, town'). For explicatory purposes, the PGN-markers will be separated from the noun stem by means of a full stop or + in this article. ${ }^{4}$

by Nama through the work of missionaries in the $19^{\text {th }}$ century. The spellings Khoi and Khoikhoi are obsolete and should be replaced by the linguistically correct spellings Khoe and Khoekhoe, respectively (pronounced as $o+e$, not as Afrikaans $o e$ ). The language will henceforth be referred to as Khoekhoe.

3 "Khoe" refers to the family which is referred to as "Central Khoesaan" in Greenberg's (1963) "Khoisan" phylum.

4 A few remarks may enhance the reading of the Khoekhoe words. Khoekhoe uses four primary click articulations, each with five click releases (not described here):

/ dental click (as in English tut-tut-tut)

// lateral click (as when driving a horse)

! alveolar click (a relatively hollow sound produced by arching the tongue backwards when releasing the click)

$\neq \quad$ palatal click (a relatively thin sound produced by pealing the tip of the tongue downwards when releasing the click).

Khoekhoe distinguishes between oral and nasalised vowels. The latter are written with a circumflex, e.g. $\hat{a}$. The orthography erroneously distinguishes between "short" and "long" oral vowels. "Long" oral vowels (which actually are juxtaposed identical vowels) are indicated by a macron above the vowel, e.g. $\bar{a}$. Khoekhoe makes no distinction between voiced and voiceless plosives; all are (moderately) voiceless. A distinction in spelling, 


\section{Loans of Dutch origin}

While it is not always evident whether a word was borrowed by Khoekhoe during the early Cape Dutch period, or more recently from earlier or later versions of Afrikaans, certain loans are revealed as early loans by traces of Dutch suffixes, particularly the plural -en. Obvious instances are purukhoe.b ('trousers') and rkhoe.s/horokhoe.s ('skirt'). If these words were loans from (modern) Afrikaans, then they should have been *puruk.i and *rōk.s/horok.s, respectively. The additional, third syllable khoe can satisfactorily be accounted for by the Dutch plural -en, as in broeken ('trousers') and rokken ('skirts'). Borrowing was facilitated by the fact that the Khoekhoe third-person neuter-gender plural PGN-marker is $-n$. The similarity of the plural Khoekhoe loans to the Dutch sources is thus quite apparent: broeken > purukhoe.n; rokken > horokhoe.n/rökhoe. $n^{5}$ These two words thus bear testimony to early contacts and concomitant cultural adaptation with regard to clothing habits. Such clothing was, of course, also adopted by the Bantu peoples of Southern Africa, but - remarkably - in most languages the terms were adopted not directly from Dutch but from a Khoe language, as is evident from the labial approximant $-w$ - in the Bantu loans: cf. Zulu/Xhosa ibhulukhwe; Sotho borikhoe; Tswana borokgwe; Yeyi urukhwe; Lozi/Kololo bulukwe/bulikwe; Herero omburukweva; ${ }^{6}$ Ndonga (Wambo) ombulukweya, ohulukweya; Kwanyama (Wambo) ombulukwewa; Kwangali mburuk(w)eva; Manyo mburukweva; Mbukushu maghurukwe. The word for "skirt/dress" (rok) was not borrowed as widely as the term for "trousers", probably because indigenous words for skirt-like dresses were already available for semantic shift to accommodate the European-style dress. (But cf., inter alia, Xhosa ilokhwe, Herero ohorokweva, Ndonga ohulukweya, and Shona rogwe.)

As with the adoption of clicks, the circumstances that lead to the adoption of the word for "trousers" in certain Bantu languages (as far north as Yeyi in northern Botswana and the Eastern Caprivi, and also some Kavango languages) must not be due to direct contact with Cape Khoe, but to diffusion of the words from Kalahari Khoe languages; e.g. brukhoe in Naro (near Ghanzi) and burukoe/hurukwe in Khwe of the Western Caprivi. On the other hand, borrowings by languages within South Africa (like Sotho) may indeed be evidence of the wider distribution of (Cape) Khoe speakers in the $17^{\text {th }}$ century.

The fact that Lozi is spoken in Zambia and the Eastern Caprivi does not imply that adoption of the words took place as far north as Barotseland. Rather, the Makololo, a Sotho tribe, would have adopted the word before they emigrated from South Africa in the early 1830s as a result of the Difaqane raids by Shaka Zulu. Their departure is thus a terminus ante quem, indicating that the Dutch words for "trousers" and "skirt" must have been adopted by the Cape Khoe during the $18^{\text {th }}$ century at the latest.

however, is maintained to indicate lexically distinctive tone on the subsequent sonorants: $p, t$ and $k$ signify a higher tone melody and $b, d$ and $g$ a lower tone melody.

5 As will be elaborated on in section 5, Khoekhoe occasionally introduces epenthetic vowels into consonant clusters of borrowed words to maintain CV alternation.

${ }^{6}$ Note the close resemblance to the Khoekhoe words with the third-person masculine singular PGN-marker $-b$ and the oblique case suffix $-a$, indicating long trousers (purukhoeba) and skirts (horokhoeba). The Herero and Khoe came into contact only in the $19^{\text {th }}$ century. As there was no direct contact between the Khoe (Nama) and the Bantu in northern Namibia then, it must be assumed that the loanwords were transmitted to Oshiwambo and - probably indirectly - the Kavango languages via Herero. It is not unlikely that geographically remote languages like Shona and Lozi may also have acquired these loans indirectly via other Bantu neighbours. 
Furthermore, Khoekhoe loans seem to reveal their likely Dutch origin by means of extra syllables that do not occur in Afrikaans, inter alia:

$\begin{array}{llll}\text { farkhe.b (pl. farkhe.n) } & \mathrm{n} . & \text { pig, boar } & <\text { Du. sg. Varken } \\ \text { ferkhe.b } & \mathrm{n} . & \text { (table)fork } & <\text { Du. pl. vorken, cf. Afr. vurk } \\ \text { kunube.s } & \mathrm{n} . & \text { button } & <\text { Du. pl. knopen } \\ \text { wekhe.b } & \text { n. } & \text { week } & <\text { Du. pl. weken } \\ \text { tolkhoe } & \text { v.t. } & \text { interpret, translate orally } & <\text { Du. tolken }\end{array}$

A true Khoekhoe word emerged next to the loan farkhe.b when domestic pigs were encountered: $h \bar{a} g \bar{u} b$, a compound noun consisting of $h \bar{a} b$ ('horse') + gū $b$ ('sheep'), literally a "horse(like)-sheep", alluding to the size of a sheep and the short-haired hide of a horse. Furthermore, words that appear to be of Dutch rather than Afrikaans origin include, inter alia:

$\begin{array}{llll}\text { kleigi.s } & \text { n. } & \text { saddle-cloth } & \text { < Du. kleedje, Afr. } \text { kleedjie }^{7} \\ \text { süro. }{ }^{8} & \text { n. } & \text { stock, broth, clear soup } & \text { < Du. soep, cf. Afr. sop } \\ \text { matare } & \text { v.t. } & \text { pay } & \text { < Du. betalen, cf. Afr. betaal } \\ \text { miki.s } & \text { n. } & \begin{array}{l}\text { paternal (consanguineous) aunt, i.e. } \\ \text { father's sister }\end{array} & <\text { Du. moeke } \\ \text { ome.b } & \text { n. } & \text { maternal (consaneous) uncle } & <\text { Du. ome, oom }\end{array}$

The last two loanwords in the list above are two of several loans from Dutch/Afrikaans that are used as kinship terms.

\section{Kinship terminology}

Kinship terms that have been adopted are in most instances "non-controversial" in the sense that they refer to relatives whose relationship and function is roughly similar to that of the European system and hence are largely compatible in their semantic extension. An exception in this regard is ome.b, as it refers to one's mother's elder brother (elder maternal uncle), who - as is also the case in Bantu cultures - has a special role in Khoe kinship systems. Ome.b is phonotactically (and tonologically) irregular, as the sequence $/ o+\mathrm{Nasal}+e /$ does not otherwise appear in Khoekhoe roots. It is an early loan from the Dutch ome, a variant of oom ('uncle'). ${ }^{9}$ The original Khoekhoe term was Inao(sa).b, which is a term with a rather wide denotation extending also to all (male) consanguineous or affinal ancestors of the grandparental generation. Grandrelatives belong(ed) to the category of joking relatives, as opposed to avoidance relatives. All relatives of the parental generation are avoidance relatives (i.e. have to be treated with particular deferential behaviour) with the exception of one's mother's brother(s). One's mother's brother, ome.b, was more subject to joking behaviour from his sister's son (nephew) than the grandrelatives classified as I/nao(sa).n. The relationship involved mutual ridiculing. $\mathrm{He}$ had a special role as provider for his sister's son in that the latter was allowed to practise cattleor stock-snatching at his maternal uncle's expense. The mother's brother would, moreover,

\footnotetext{
${ }^{7}$ The diphthongised pronunciation of the doubled vowels $e e$ as [Ie] in Afrikaans is an indication that the Khoekhoe word kleigi.s is shaped on the Dutch pronunciation.

${ }^{8}$-ro is a diminutive suffix.

${ }^{9}$ Cf. the original Dutch form ohem and the now archaic German form Oheim ('uncle').
} 
replace any defective goods of his sister's children with better ones. ${ }^{10}$ Today, the Dutch loan ome is more frequently used as a term of address than Inao.

One's mother's younger brother, while being generically categorised as I/nao(sa).b, is also identified with loans of Dutch origin: either omero.b ('little omeb'; -ro is a diminutive suffix) or - especially among the Nama - kli-om.mi (Du. klein oom or 'little uncle').

The term miki.s derived from the Dutch moeke (term of endearment for 'mother'). The former generally refers to one's father's sister, and - especially among the Nama - to the wife of one's mother's brother (ome.b) and rarely also to one's father's brother's wife. Today, the generally used term for one's father's sister, miki.s, replaces an old term ai.s kai.s ('great/senior mother'), according to Hoernlé (1925, cited in Barnard 1992: 290).

Other kinship terms that are in frequent use today, among especially the Nama, include:

\begin{tabular}{|c|c|c|c|}
\hline aputi.b & $\mathrm{n}$. & eldest brother & $<$ Afr. ou boet(ie) \\
\hline ausī.s & $\mathrm{n}$. & eldest sister & $<$ Afr. ousus \\
\hline sisiro.s, sīro.s & n. & elder but not eldest sister & $<$ Afr. sussie? \\
\hline buda.b & $\mathrm{n}$. & brother & $\begin{array}{l}<\text { Du. broeder } \\
>\text { Afr. boeta? }\end{array}$ \\
\hline klīmâ.s, mikidā.s & $\mathrm{n}$. & $\begin{array}{l}\text { father's younger brother's } \\
\text { wife, mother's younger sister }\end{array}$ & $<$ Afr. kleinma \\
\hline $\begin{array}{l}\text { auma.s } \\
h \bar{a} h \text { baha } b\end{array}$ & n. & grandmother, any grand-aunt & $\begin{array}{l}<\text { Du./Afr. ouma } \\
<\text { Du/Afr. na/nan }\end{array}$ \\
\hline
\end{tabular}

An uncommon case of bidirectional borrowing may be the Khoekhoe word buda.b ('brother'). It is likely that Khoekhoe buda.b was derived from Dutch broeder or German Bruder. Afrikaans subsequently seems to have adopted the Khoekhoe loan buda.b as boeta.

\section{Adoptions}

Adoptions are morphemic, non-integrated importations, i.e. loanwords that have been adopted with no or minimal phonological adaptations. For the purposes of this article, such importations are not required to retain their original spelling. Generally, the more bilingual the speakers are, the more readily they will accommodate the phonology of the source language in the loans. Hence the Nama and Orlam, who tended to shift to Afrikaans especially during the apartheid era, tend to rely less on phonological accommodation of the loans than the Damara and Haillom. Often it is a moot point whether such words should already be accepted as part of the Khoekhoe lexical inventory, or whether their use should be considered as code switching. Therefore, the following examples will be listed as mere illustrations without discussion:

$\begin{array}{llll}\text { bantam } & \text { a. } & \text { banded/belted (of animal) } & <\text { Afr. bandom, bantom, bantam } \\ \text { fadu.s } & \text { n. } & \text { dishcloth/-rag, tea-towel } & <\text { Afr. vadoek } \\ \text { filsi.b } & \text { n. } & \text { syphilis } & <\text { Afr. vuilsiekte } \\ \text { kâia.n } & \text { n. } & \text { greaves } & <\text { Afr. kaiings } \\ \text { klouhamer.s } & \text { n. } & \text { carpenter's hammer } & <\text { Afr. klouhamer }\end{array}$

\footnotetext{
${ }^{10}$ Cf. Barnard (1992: 171) for the same customs among the !Gora.na (Korana).
} 


\begin{tabular}{|c|c|c|c|}
\hline komigi.s & n. & $\begin{array}{l}\text { bowl (used for drinking by } \\
\text { male head of house) }\end{array}$ & $<$ Du. kommetje, Afr. kommetjie \\
\hline kriba.s & n. & wheelbarrow & $<$ Afr. kruiwa \\
\hline kuip.s & n. & $\begin{array}{l}\text { tub (esp. one used for } \\
\text { softening hide) }\end{array}$ & $<$ Du./Afr. kuip \\
\hline Namastap. $i$ & n. & traditional Nama dance & $<$ Afr. Namastap \\
\hline sais $\bar{a} . b$ & n. & $\begin{array}{l}\text { side pocket (part of women's } \\
\text { traditional dress) }\end{array}$ & $<$ Afr. sysak \\
\hline sampan.s & n. & tick of Argasidae family & $<$ Afr. tampan (origin uncertain) \\
\hline tapaga. $-i$ & n. & $\begin{array}{l}\text { tobacco, }(\text { commercial }) \\
\text { tobacco plant }\end{array}$ & $<$ Du./Afr. tabak \\
\hline tawu.s & $\mathrm{n}$. & $\begin{array}{l}\text { quirt, short whip/sjambok (as } \\
\text { used with donkey carts) }\end{array}$ & $<$ Afr. tabboes \\
\hline
\end{tabular}

\section{Integrated loanwords}

Fully integrated loanwords undergo phonological nativisation. While the Khoekhoe language does not adhere to consonant-vowel alternation as strictly as Bantu languages do, epenthesis the intrusion of a vowel between consonants - nevertheless occurs occasionally. (In the following examples, epenthetic vowels are bolded.) A rule that is adhered to quite strictly is that roots must be disyllabic, as they must be bimoraic in order to accommodate a tonal melody consisting of two tones, e.g. drō [törò] or [trö̀o] ('dry up'). As previously stated, juxtaposed identical vowels are erroneously treated as long vowels in the standard Khoekhoe orthography (indicated by a macron, viz. $d r \bar{o}$ ).

\begin{tabular}{|c|c|c|c|}
\hline aili & v.i. & suffer from delirium, rave & $<$ Du. ijlen, Afr. $y l$ \\
\hline bankoro & v.i. & go bankrupt & $<$ Afr. bankrot \\
\hline bili & v.i. & flow & $<$ Afr. vloei \\
\hline bili.s & n. & bedbug, house bug & $<$ Afr. weeluis/Du. weegluis \\
\hline brōxo.s, boroxo.s & n. & bridge & $<$ Afr. brug \\
\hline doro, $d r \overline{\boldsymbol{o}}$ & v.i. & dry up, evaporate, boil away & $<$ Afr. droog \\
\hline flī, fili & v.i. & fly & $<$ Afr. vlie $(g)$ \\
\hline hurusi.b, rūsi.b & n. & rust & $<$ Afr. roes \\
\hline
\end{tabular}

The variant $r \overline{\boldsymbol{u}}$ si.b overrides the Khoekhoe rule that the alveolar tap/flap $r$ normally only occurs intervocalically. The insertion of final $i$ seems to be due to the interpretation of $s i$ as an abstract suffix. The expected nominal derivation would be disyllabic *hurus.si or *rūs.si.

\begin{tabular}{|c|c|c|c|}
\hline $\begin{array}{l}\text { kini } \\
\text { lä.b [Nama], } \\
\text { labi.b [Damara] }\end{array}$ & $\begin{array}{l}\text { v.t. } \\
\text { n. }\end{array}$ & $\begin{array}{l}\text { knead } \\
\text { patch, (cleaning) cloth }\end{array}$ & $\begin{array}{l}<\text { Afr. knie } \\
<\text { Afr. lappie }\end{array}$ \\
\hline legiri.n, negiri.n & n. & sweets & $<$ Afr. lekkers \\
\hline matare & v.t. & pay & $<$ Du. betalen \\
\hline muru.b & n. & coffee grounds, tea leaves & $<$ Afr. moer \\
\hline$p \bar{a} .-i$ & n. & porridge & $<$ Du./Afr. pap \\
\hline pēt.-i & $\mathrm{n}$. & wick & $<$ Du./Afr. pit \\
\hline
\end{tabular}




\begin{tabular}{|c|c|c|c|}
\hline sinibe.s & n. & perky/pert girl/woman, & $<$ Du./Afr. snippie \\
\hline & n. & troop, armed forces, army & $<$ Du./Afr. $\operatorname{troep}(e)$ \\
\hline xarao.b/s & n. & spade/shovel & $<$ Du./Afr. graaf \\
\hline
\end{tabular}

In certain loanwords, consonants are adapted to the Khoekhoe phonological system. (Recall that Khoekhoe only has (moderately) voiceless plosives; the respective letters $p, t, k$ and $b, d$, $g$ do not distinguish voicing but tonal height.) As a result, Khoekhoe speakers frequently insist, when prompted, that the Afrikaans words dak ('roof') and tak ('branch') should be pronounced with low and high tone, respectively, when speaking Afrikaans. Khoekhoe has no labial or alveolar continuants in root-initial position, only plosives $[\mathrm{p}, \mathrm{t}]$. [v/ß] and $[\mathrm{r} / \mathrm{r}]$ occur only intervocalically in roots, thus as $\mathrm{C}_{2}$ in $\mathrm{C}_{1} \mathrm{VC}_{2} \mathrm{~V}$. Hence words like Afrikaans weeg ('weigh') may be adapted to bee if the speaker is not fully bilingual. While [f] is not a Khoekhoe sound, it is nevertheless adopted without change when in initial position (but see halhal below). Likewise, [1] is readily accommodated. The lateral alveolar [1] is not found in the Nama dialects, but may be a free or regional variant of the alveolar nasal [n] in some northern Damara dialects like Haillom and $¥ \bar{A}$ khoe. The following loans provide some instances of more obvious phonological nativisation or accommodation, as the case may be:

\begin{tabular}{|c|c|c|c|}
\hline bapu.s & $\mathrm{n}$. & pumpkin & $<$ Afr. pampoen \\
\hline$b \bar{e} . b$ & $\mathrm{n}$. & pair of scales & $<$ Afr.weeg $($ skaal $)$ \\
\hline danimen.- $i$ & n. & dynamite & $<$ Afr. dinamiet \\
\hline flī.s & n. & mouth-organ & $<$ Afr. (mond)fluit \\
\hline flō.b, folo.b, (flor.ri) & n. & Namaqua dove & $<$ Afr. vö̈l? \\
\hline halhal & v.t. & $\begin{array}{l}\text { do s.th. half-heartedly/not } \\
\text { properly }\end{array}$ & $<$ Afr. half-half (doen) \\
\hline karnaiki.b & n. & stye & $<$ Afr. karkatjie \\
\hline kurlabe.s & n. & butterfly & $<$ Afr. skoe(n)lapper \\
\hline
\end{tabular}

\section{Hybrids}

Lexical hybrids are composite loanwords in which one part is borrowed from the source language, while another is substituted by a word from the target language. Hybrid loans abound in Khoekhoe, as is illustrated in the examples below.

\begin{tabular}{|c|c|c|c|}
\hline borkhuru & v.t. & drill hole through (s.th.) & $\begin{array}{l}<\text { Afr. boor (drill) }+ \text { khuru (make } \\
\text { hole right through) }\end{array}$ \\
\hline Denstaxtsē.s & $\mathrm{n}$. & Tuesday & $\begin{array}{l}<\text { Afr. Dinsdag (Tuesday) }+t s \bar{e} . s \\
\text { (day) }\end{array}$ \\
\hline forkhō.s & $\mathrm{n}$. & apron & $\begin{array}{l}<\text { Afr. voor (skoot) lit.: (front(- } \\
\text { lap)) + khō.s (hide, leather) }\end{array}$ \\
\hline gūsker.s & n. & sheep-shears & $<g \bar{u} . s$ (sheep) + Afr. skêr (shears) \\
\hline hātom.s & n. & horse's bridle & $\begin{array}{l}<\text { ha. } b \text { (horse) + Afr. toom } \\
\text { (bridle) }\end{array}$ \\
\hline$\hat{\imath}($ ga $)$ kinibe. $b$ & $\mathrm{n}$. & $\begin{array}{l}\text { good-looker (of person } \\
\text { /animal), beauty (of e.g. car) }\end{array}$ & $\begin{array}{l}<\hat{\imath} \text { (become pretty) }+ \text { Afr. snippie } \\
\text { (pert woman)? }\end{array}$ \\
\hline
\end{tabular}

\footnotetext{
${ }^{11}$ Note the semantic shift in the second meaning from Afrikaans "voorbarige/bemoeisieke/bitsige meisie of vrou".
} 


\begin{tabular}{|c|c|c|c|}
\hline Jodel/î.b & n. & Jew & $\begin{array}{l}<\text { Afr. Jode }(\text { Jews })+/ \hat{\imath} \\
{[\text { lexeme used for categorising] }}\end{array}$ \\
\hline khaoduru & v.i. & $\begin{array}{l}\text { move/drive/go backwards, } \\
\text { reverse (of car) }\end{array}$ & $\begin{array}{l}<\text { khao.s (posterior) + Afr. tru } \\
\text { (reverse) }\end{array}$ \\
\hline koetara.s & n. & woman in childbed & $\begin{array}{l}<\text { Du./Afr. kooi (bed) + tara.s } \\
\text { (woman) }\end{array}$ \\
\hline lantern!amlae.s & n. & hurricane-lamp & $\begin{array}{l}<\text { Afr. lantern (lantern) } \\
+ \text { !amlae.s (lamp) }\end{array}$ \\
\hline leli!khā.s & n. & lily & $<$ Afr. lelie (lily) $+! k h \bar{a} . s$ (flower) \\
\hline smokelxū.n & n. & contraband & $\begin{array}{l}<\text { Afr. smokkel (smuggle) }+ \\
x \bar{u} . n \text { (things) }\end{array}$ \\
\hline spul//gam.mi & n. & rinsing-water & $\begin{array}{l}<\text { Afr. spoel (rinse) + /lgam.mi } \\
\text { (water) }\end{array}$ \\
\hline swawelani.b & n. & swallow, swift & $\begin{array}{l}<\text { Afr. swael (swallow) + ani.b } \\
\text { (bird) }\end{array}$ \\
\hline tuisi [Damara] & v.i. & live, reside & $\begin{array}{l}<\text { Afr. tuis? (home) + Khoekhoe } \\
\text { postposition ai/i (on)? }\end{array}$ \\
\hline lgûdoro & v.i. & boil away, boil dry & $<\lg \hat{u}$ (boil) + Afr. droog (dry) \\
\hline Ilnōtaxū.n & n. & $\begin{array}{l}\text { (still usable) jumble/ } \\
\text { rummage }\end{array}$ & $\begin{array}{l}<\text { Afr. nodig? (necessary) }+ \\
x \bar{u} . n \text { (things) }\end{array}$ \\
\hline !hüdan.s & n. & Namastap & $\begin{array}{l}<! h \bar{u} . b(\text { earth })+\text { Afr. dans } \\
\text { (dance) }\end{array}$ \\
\hline \#gawunal.i & n. & knitting needle & $\begin{array}{l}<\neq g a w u \text { (plait) + Afr. naald } \\
\text { (needle) }\end{array}$ \\
\hline
\end{tabular}

\section{Calques: Which directionality?}

Calques are literal word-for-word/root-for-root translations of compound loanwords. It is an inherent problem of calques that, because of the translation, it is not always obvious in which direction the borrowing occurred, unless the social context or some other linguistic aspect provides a clue. Whenever the Afrikaans word can be traced to an etymon other than from Khoe (especially from Dutch), then it is beyond doubt that Afrikaans (or Dutch itself) is the source language. However, substrate calques also occur in Afrikaans (cf. section 8.1).

\section{Khoekhoe}

anidana (chicken + head)

hōkhâixū.n (pick up/find + $\mathrm{n}$. things)

huibē (help + disappear)

$m \hat{\imath} x \bar{u} .-i$ (say + thing)

laellgau.b (fire + arrow)

lawałai. $b^{12}$ (red + foot)

\section{Afrikaans}

v.i. hoenderkop (chicken + head)

optelgoed (pick up/find + things)

v.t. $\quad$ weghelp (away + help)

n. sêgoed

n. vuurpyl (fire + arrow)

n. pienkvoet (pink + foot $)$

\section{Meaning}

adj. (bec.) drunk/tipsy

n. (worthless) things found/picked up

v.t. help (s.o.) to get on their way

n. platitude, repartee

n. rocket

n. pink-foot, newborn, i.e. baby

\footnotetext{
${ }^{12}$ The Khoekhoe word for "pink" is the less used word lawara. The colour mismatch suggests that the source language was Afrikaans or Dutch.
} 


\begin{tabular}{|c|c|c|c|c|}
\hline lkhā $\neq g \bar{a}$ (body + insert) & v.t. & lyf wegsteek (body + hide) & & shirk (work) \\
\hline $\begin{array}{l}\text { lui-aosen.ni (rock + } \\
\text { sweat) }\end{array}$ & n. & klipsweet (rock + sweat) & n. & $\begin{array}{l}\text { solidified urine of } \\
\text { rock hyrax, hyraceum }\end{array}$ \\
\hline 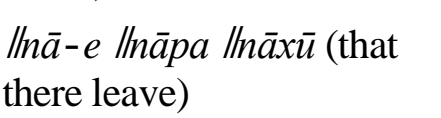 & n. & $\begin{array}{l}\text { dit daar gelaat (this there } \\
\text { left) }\end{array}$ & & be that as it may \\
\hline $\begin{array}{l}\text { Ilnā fgâallae.b (fall + enter/ } \\
\text { join + time) }\end{array}$ & n. & invaltyd (fall in + time) & n. & $\begin{array}{l}\text { time to start work; } \\
\text { time to fall in line }\end{array}$ \\
\hline $\begin{array}{l}\text { !ae /hao (jump + meet, get } \\
\text { together) }\end{array}$ & n. & $\begin{array}{l}\text { aanmekaarspring (together } \\
+ \text { jump) }\end{array}$ & & fight \\
\hline !âu!gae.s (hyrax + adder) & n. & $\begin{array}{l}\text { dassie-adder (hyrax + } \\
\text { adder) }\end{array}$ & n. & mythical adder ${ }^{13}$ \\
\hline !nari! $\bar{o} . b$ (drive + axe) & n. & rybyl & & adze \\
\hline Anaubē (hit + disappear) & v.t. & wegslaan (away + hit) & v.t. & down/quaff (drink) \\
\hline $\begin{array}{l}\text { Inâi Ilnâi (pull taut; erect } \\
\text { (causative)) }\end{array}$ & v.t. & $\begin{array}{l}\text { draad trek (vulgar: wire }+ \\
\text { pull) }\end{array}$ & & masturbate (of male) \\
\hline
\end{tabular}

Rybyl refers to the axe that was part of the equipment of an ox-wagon. According to oral history (Daniel Dâusab, pers. comm.), the /Khowesen (Witbooi Oorlam) acquired the right to settle at Gibeon in the 1850 s by paying seven rybyle to the Kail/khaun (Rooinasie Nama). Rybyl does not appear in the Woordeboek van die Afrikaanse Taal (WAT). This word may be an instance of a calque that is not truly a "borrowing" or adoption, in the sense that it was translated by the speakers of the target/recipient language (Afrikaans), as is normally the case. In this case it seems plausible that the speakers of the source language (the extensively bilingual Orlam-Nama) have provided the translation themselves as "imposition", to use Johanson's (2000) ${ }^{14}$ terminology. The word was short-lived, however, as it became obsolete with the demise of ox-wagons. Lexical "impositions" (or "contributions", as I prefer to call them by a less uncompromising term) would probably warrant further investigation in Orange River Afrikaans and other varieties spoken by strongly hybridised Khoe (i.e. so-called "Coloureds" or Orlam), as it is to be expected that they supplied the superstrate language they were aspiring to with calqued concepts from their original Khoekhoe vernacular, even though such impositions may not have found their way into standard Afrikaans.

The Afrikaans taboo expression draad trek - which, according to Van Wyk, Cloete, Jordaan, Liebenberg and Lubbe (2003: 96), developed in Afrikaans on its own - represents a rare type of calque. The Khoekhoe source is the polysemous intransitive verb Ilnâi (1. vulgar: become erect (of organ); 2. informal: become mad with rage). ${ }^{15}$ The duplication of the root (with appropriate derivational tone), Innâil/nâi , forms a causative transitive verb meaning "stiffen", hence "1. pull taut/stiff (e.g. wire); 2. vulgar: stimulate to erection", apart from "enrage (s.o.)". Afrikaans has calqued the "innocent" meaning of Inâi llnâi (i.e. "pull taut") to form a (frivolous) euphemism for "masturbate", viz. draad trek. This reflected taboo meaning of the Afrikaans expression has in turn led to the alternative "safe" expression draad span for "pulling a fence wire", analogous to German "einen Draht spannen".

\footnotetext{
${ }^{13}$ The origin of this word is in Khoe mythology.

14 Johanson (2000: 116, in Heine and Kuteva 2005: 13) states that "[i]n the case of imposition, speakers of a primary code insert (or "carry over") copies of their own code into their variety of a dominant code."

${ }^{15}$ Cf. Haacke and Eiseb (2002: 287).
} 


\section{Grammatical accessibility and intertranslateability}

The working language in the Khoekhoegowab Dictionary Project ${ }^{16}$ was Afrikaans, as the Khoekhoe co-author was more fluent in Afrikaans and German than English. Hence the meanings of Khoekhoe words were first discussed in Afrikaans before they were rendered in English.

\subsection{Khoekhoe serial verbs and Afrikaans compound verbs}

The impression was ever-present that, structurally, Khoekhoe compound and serial verbs ${ }^{17}$ had more direct equivalents in Afrikaans than in English, and that intertranslateability is thus higher between Khoekhoe and Afrikaans than between Khoekhoe and English. English equivalents usually amount to phrasal verbs, while in Afrikaans (as in German) the preposition is unified with the infinitive form of the verb, e.g. Khoekhoe fnaube (lit.: hit + disappear) would be rendered in English as "hit away; smack away (hand)". In Afrikaans, however, this meaning in the infinitive is rendered as one word: wegslaan. Such words are easy to access for Khoekhoe because of the high degree of translational equivalence between Khoekhoe serial verbs and Afrikaans compound verbs using adverbs: Afrikaans verbs using, inter alia, adverbs like af ('down') or op ('up') in the infinitive, or prefixes like mis- ('miss, do wrongly'), are also rendered as single serial verbs in Khoekhoe, as these prepositions or

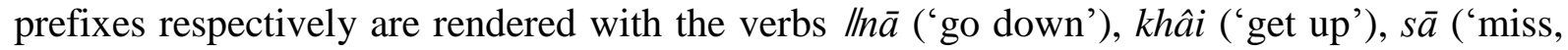
do wrongly'). For example:
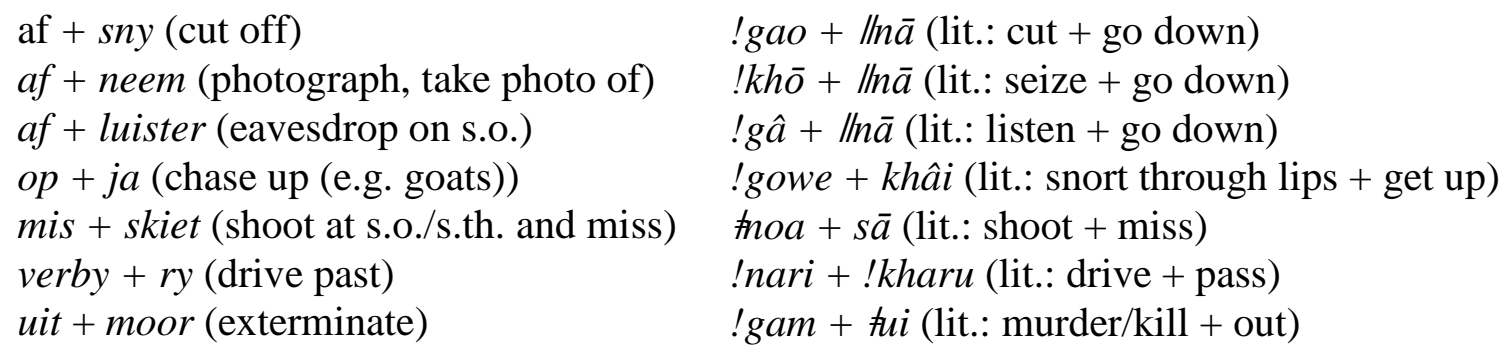

The fact that both Afrikaans and Khoekhoe render such infinitives as single words in a predictable way may invite the impression that such close equivalents are all easily accessible calques, probably from Cape Dutch or Afrikaans to the Khoekhoe substrate. Den Besten (2013: 455) argues that preposition-verb compounds arose (only) in "Khoekhoe Afrikaans" by interference from Cape Khoekhoe, but that general Afrikaans has adopted "double" verbs from Khoekhoe. He explains as follows (italics outside of the two examples are my own):

Probably due to reanalysis of $\mathrm{V}-\mathrm{AUX}$ and $\mathrm{AUX}-\mathrm{V}$ sequences as single verbs in [Cape Dutch Pidgin] - prior to the acquisition of V2 - Khoekhoe Afrikaans developed a "double" V2 pattern which was taken over in general Afrikaans. Compare:

\footnotetext{
${ }^{16}$ The project in which, inter alia, Haacke and Eiseb (2002) and Haacke, Eiseb and Gericke (2010) were compiled.

${ }^{17}$ Serial verbs are verb juxtapositions that, in their most typical occurrence, have a composite meaning; occur in a single clause with no overt signs of co-ordination; (in Khoekhoe) form a single tonological unit when contiguous; cannot be differently marked for tense, aspect, modality or polarity; cannot be separately passivised; share one or more of the arguments, and are not independently marked for the respective verbs (cf. Haacke (2014)).
} 


\author{
Daar bly staan hy \\ There remain stand he
}

Similarly, reanalysis of Dutch particle verbs in [Cape Dutch Pidgin] created preposition + verb compounds in Khoekhoe Afrikaans, as in (11), which was [sic] not borrowed into other varieties of Afrikaans [...]:

$$
\begin{aligned}
& \text { Aan-ja vir my die skaap } \\
& \text { on-drive for me the sheep }
\end{aligned}
$$

Both types of reanalysis may be due to interference from Khoekhoe, where $\mathrm{V}$ $+\mathrm{V}$ and verb + postposition compounds are quite normal.

Den Besten's argument can be confirmed, as the use of serial verbs and verbs incorporating object-nouns and postpositions are well established in the Khoe family beyond Khoekhoe. Serial verbs are also found in Kalahari Khoe languages like Naro and Gui in Botswana, if not others. ${ }^{18}$ While it is difficult to prove, it is plausible that the process of borrowing "doubled" verbs initially went from Khoekhoe to Cape Dutch/Afrikaans during the time that the replication was established in the superstrate language through interference, but that actual calquing from Afrikaans to Khoekhoe became more frequent at a later stage once parallel structures between the languages existed. Thus, for instance, the literal meaning of Khoekhoe łnaube ('hit away; smack away (hand)') may have been adopted in Afrikaans wegslaan. Conversely, the figurative meaning of, e.g., "down/quaff (a drink)" may have been adopted by Khoekhoe from Afrikaans. Further instances of figurative Khoekhoe calques may be:

$\begin{array}{lll}\text { !khō/lnā (lit.: seize + go down) } & \text { photograph } & \text { afneem } \\ \text { kurukhâi (lit.: build + get up) } & \text { rebuild (e.g. old car) } & \text { opbou }\end{array}$

Opbou in the sense of "rebuild, renovate" is not found in the WAT. However, from personal communication with various Afrikaners - including some from South Africa - this word does seem to belong to standard Afrikaans, as these speakers have confirmed that they know the word.

\title{
8.2 Grammatical replication and relexification
}

A common instance of grammatical replication, i.e. where a derivational Afrikaans morpheme is suffixed to a Khoekhoe lexeme, is the use of the superlative adjectival suffix -ste (Eng.: -est). For example:

$\begin{array}{llll}\text { Kaiste } a o b \quad g e \quad n \hat{\imath} & \text { aimâ } \\ \text { big+SUPERL man DECL FUT } & \text { take lead }^{19} \\ \text { The biggest man shall take the lead }\end{array}$

\footnotetext{
${ }^{18}$ Cf. Visser (2010) and Nakagawa (2006, in Haacke (2014)).

${ }^{19}$ ADV.SUF.: adverbialising suffix, C: common gender, DECL: declarative sentence type marker, F: feminine, FUT: future, IND: indicative (mood), M: masculine, OBL: oblique (case), PAST.AUX: past auxiliary, PGN: person-gender-number marker, POSS.PRON.: possessive pronoun, PL: plural, PRES.STAT.: present stative, REC.P.: recent past, SG: singular, SUPERL: superlative suffix, STAT: stative aspect, $1 / 2 / 3: 1^{\text {st }} / 2^{\text {nd }} / 3^{\text {rd }}$ person.
} 
Khoekhoe, like many African languages, has no comparative and superlative forms of adjectives or verbs. Instead, periphrastic devices are conventionally used. For example:

$\begin{array}{llllllll}\text { Hoan } & x a & a & k a i & a o b & g e & n \hat{\imath} & \text { aimâ } \\ \text { all } & \text { from } & \text { PRES.STAT. } & \text { big } & \text { man ... } & & \end{array}$

The man who is big from (the view of) all ...

Speakers of Khoekhoe tend to avoid this relatively cumbersome circumvention by simply appending the Afrikaans superlative suffix -ste to the Khoekhoe adjective. However, this kind of replication is not readily used with the Afrikaans comparative -er.

While the construction above uses a Khoekhoe lexeme with an Afrikaans grammatical morpheme, the opposite hybridisation also exists in the form of relexification (of Khoekhoe grammar with Afrikaans lexicon): an Afrikaans adverb can be integrated into Khoekhoe syntax and morphology with a Khoekhoe grammatical morpheme, the adverbialising suffix $-s e$, in order to avoid a circumvention; cf. lāt + se $<$ Afr. laat ('late'), frü $+\boldsymbol{s} \boldsymbol{e}<$ Afr. vroeg ('early'):

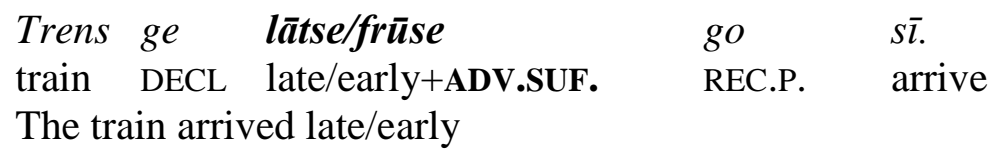

Two Germanic adverbs have been fully integrated into Khoekhoe, although the exact method is not clear as the suffix - $b a$ cannot be accounted for with certainty: tox(o)ba (Du./Afr. imploring tog, Ger. doch) and noxoba (Du./Afr. nog, Ger. noch 'more, still'):

(4) Hui te re, toxoba! cf. Afr. Help my tog! ('Do help me, please!')

(5) Noxoba gu ge nî $/ k h \bar{\imath}$. cf. Afr. Hulle sal nog kom. ('They will still come.')

The origin of the final $-b a$ is not clear. It appears to be formed by analogy with adverbials like tsuxuba ('at/by night, during the night') and tsēb tsî tsuxuba ('by night and day'), which are based on the noun tsuxu.b ('night') with the oblique case suffix $-a$.

The Afrikaans auxiliary verb moet ('must') has acquired adverbial function in Khoekhoe and is used to convey inevitability, obligation or compulsion. For example:
Jako, satsa mut hoallae nî
fama?
Jacob you must always must/FUT show off
Jacob, must you always show off?

Khoekhoe has no particular word expressing obligation. The tense marker $n \hat{\imath}$ is used to render both the future ('shall/will') and obligation ('must').

\subsection{Honorific address}

In the northern Damara dialects of Khoekhoe, an honorific address for a single person is formed by means of a plural pro-form, especially in the common gender. For example: 


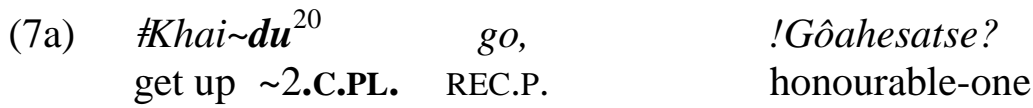

Did you (PL.) get up (well), Sir? (honorific)
fKhai $\sim$ s
go,
!Gôhesatse?
get up 2.M.SG. REC.P.
honourable-one

Did you (SG.) get up (well), Sir?

In the southern dialects of Khoekhoegowab (i.e. Nama and Orlam), the pluralisation of a subjectival pro-form - as used among the Damara - conveys disrespect rather than respect, unless the person is an in-law. The honorific address would refer to the addressee with a proper noun (personal name) or common noun (especially a kinship term). For example:
Kaidāba
\#khai b
go?
uncle+3.M.SG+OBL
get up 3. M.SG
REC.P.
Did Uncle get up (well)?

This usage is shared with Afrikaans, which likewise uses a nominal in place of a secondperson pro-form, for example:

$\begin{array}{llll}\text { Goeie môre, } & \text { Oom. } & \text { Het } & \text { Oom goed geslaap? } \\ \text { good morning } & \text { Uncle. } & \text { PAST.AUX. } & \text { Uncle well sleep+PAST }\end{array}$
Good morning, Uncle. Did you sleep well?

or
$\mathrm{Pa}$, het
Pa Pa se
geld
Dad PAST.AUX.
Dad Dad POSS.PRON.
money
ontvang?

Dad, did you receive your money?

It is not clear how the use of the (third-person) noun in place of a second-person pronoun originated, and in which language it appeared first. The editorial staff of the WAT could not provide an authoritative answer to this question (pers. comm.).

For the likely origin of the Afrikaans expression pa-hulle ('father and associates') in Khoekhoe, see Haacke in Nienaber (1994: 41-43).

\subsection{Desentential nouns}

In his article entitled South African Khoekhoe in contact with Dutch/Afrikaans, den Besten (2013: 455) draws attention to a parallel between Afrikaans and "Khoekhoe Afrikaans" syntax:

Other potential Khoekhoeisms at the phrasal level in [Khoekhoe Afrikaans] are shared with (other varieties of) Afrikaans. Thus, circumlocutions like Afrikaans hy / sy wat Piet / Anna is, in 'he/she that Pete/Anne is', in [Khoekhoe Afrikaans], also

\footnotetext{
${ }^{20}$ For explicatory purposes, the PGN-marker is separated from the preceding morpheme by means of a tilde whenever it is not grammatically part of the preceding word, irrespective of existing orthographic rules.
} 
hy wat lou is 'he that lion is', i.e. 'the lion' (Rademeyer 1938: 83f.), are reminiscent of the structure of noun phrases in Khoekhoe (e.g. Nama xam-i 'lion-3SG.M.').

This Afrikaans circumlocution amounts exactly to the underlying clause from which Khoekhoe surface nominals are derived, according to the "desentential hypothesis" advocated by Haacke (for a detailed explication, see Haacke (2006: 107 et seq.) and Haacke (2010: 205 et seq.)). Briefly, according to this hypothesis, Khoekhoe surface nouns are derived from underlying minimal sentences, i.e. sentences having only one lexeme that serves as verb and hence as predicate head. This verbal (with the stative aspect marker $a$ ) is advanced into the initial position so as to serve as host for the clitic PGN-marker that serves as subject. After deletion of the stative aspect marker, the surface noun emerges with the canonical form \#STEM.PGN\#. Thus:

$\begin{array}{llllll}(11) & * s \quad(g e) \text { a Anna }> & \text { Anna } a & s & (g e)> & {[\text { Anna.s }]_{\text {noun }}} \\ \text { PGN IND STAT Anne } & \text { Anne STAT PGN } & \text { IND } & \text { Anne+PGN } \\ \text { (she is Anne) } & \text { (She who is Anne) } & & \text { (Anne) }\end{array}$

This hypothesis independently accounts for several morphosyntactic features of Khoekhoe that otherwise are awkward to account for, inter alia, the fact that Khoekhoe has (surface) nouns in the first and second person. For example:

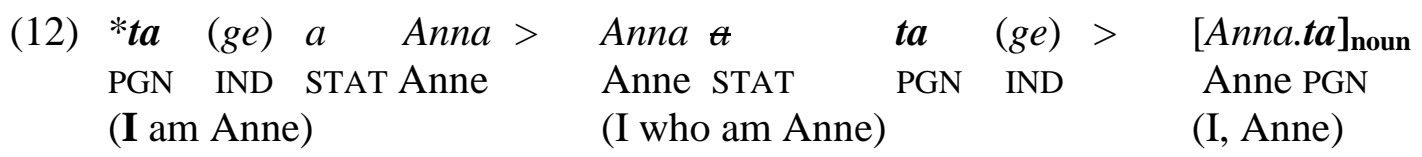

Thus, Khoekhoe may be the source of this Afrikaans circumlocution (emphatic sy / ek wat Anna is), a situation which in turn would serve as additional evidence for the validity of the desentential hypothesis.

\section{Conclusion}

While, no doubt, a substrate language (Khoekhoe) is liable to borrow more loans from a superstrate language (Dutch, Afrikaans), one should not lose sight of the influence of Khoekhoe on Cape Dutch and early Afrikaans (cf., inter alia, Ponelis (1993) on the close interaction of the societies). A number of Khoe words that are no longer known in Khoekhoe today seem to have been perpetuated in Afrikaans, e.g. boegoe ('aromatic herb'), kierie ('club'), koedoe ('kudu'), kwagga ('quagga'), oorbietjie, oribi ('oribi') or trassie ('hermaphrodite') - cf. Nienaber (1963) for extensive attempts to reconstruct etymologies.

The following Khoe loans in Afrikaans are some common instances where the etymology is beyond doubt:

dagga (cannabis)

gabba (hold a vessel to be filled)

gogga (insect, creepy-crawly)

graatjie, ghartjie (suricate)
$<$ (Cape) Khoe dāxa.b (lit.: $d \bar{a}$ (win, outdo) + -xa

(adj. suffix: inclined to ...))

$<$ Khoekhoe xawa (receive (food) in cupped

hands/container; extend cupped hands (to beg))

$<$ Khoekhoe xoxo.-i (insect, creepy-crawly)

$<$ Khoekhoe xara.b (suricate) 
narra (Acanthosicyos horrida, nara melon)

tsamma (tsama melon)
$<$ Khoekhoe!nara.s (Acanthosicyos horrida)

$<$ Khoekhoe tsama.s (Citrullus lanatus)

For centuries, Cape Dutch and Afrikaans have been the superstrate languages to which the speakers of Khoekhoegowab have aspired. It remains to be seen what influence the relegation of Afrikaans in Namibia to the status of "local language" will have on the future trend of lexical borrowing by Khoekhoe from Afrikaans.

\section{References}

Barnard, A. 1992. Hunters and herders of Southern Africa. Cambridge: Cambridge University Press.

Den Besten, H. 2013. South African Khoekhoe in contact with Dutch/Afrikaans. In R. Vossen (Ed.) The Khoesan languages. London/New York: Routledge. pp. 449-456.

Greenberg, J. 1963. The languages of Africa. Bloomington: Indiana University.

Haacke, W.H.G. 2006. Syntactic focus marking in Khoekhoe (Nama/Damara). ZAS Papers in Linguistics 46: 105-127.

Haacke, W.H.G. 2010. Naro syntax from the perspective of the desentential hypothesis: The minimal sentence. In M. Brenzinger and C. König (Eds.) Khoisan languages and linguistics: Proceedings of the 1st International Symposium January 4-8, 2003, Riezlern/Kleinwalsertal. Vol. 24. Cologne: Rüdiger Köppe Verlag. pp. 201-230.

Haacke, W.H.G. 2011. Nama als Sprachbenennung in der Koloniallinguistik DeutschSüdwestafrikas: zwischen Endonym and Exonym. In T. Stolz, C. Vossmann and B. Dewein (Eds.) Kolonialzeitliche Sprachforschung: Die Beschreibung afrikanischer und ozeanischer Sprachen zur Zeit der deutschen Kolonialherrschaft. Berlin: Akademie. pp. 139-160.

Haacke, W.H.G. 2014. The occurrence of verb serialisation in Khoe languages: Convergence or divergence? In T. Güldemann and A.-M. Fehn (Eds.) Beyond 'Khoisan': Historical relations in the Kalahari Basin. Amsterdam/Philadelphia: Benjamins. pp. 125-151.

Haacke, W.H.G. and E. Eiseb. 2002. A Khoekhoegowab dictionary with an EnglishKhoekhoegowab index. Windhoek: Gamsberg-Macmillan.

Haacke, W.H.G., E. Eiseb and C. Gericke. 2010. Khoehoegowab-Afrikaans AfrikaansKhoekhoegowab glossarium/Mîdi saogub. Windhoek: Macmillan.

Heine, B. and T. Kuteva. 2005. Language contact and grammatical change. Cambridge: Cambridge University Press.

Hoernlé, A.W. 1925. The social organization of the Nama Hottentots of Southwest Africa. American Anthropologist 27(1): 1-24. 
Johanson, L. 2000. Linguistic convergence in the Volga area. In D. Gilberts, J. Nerbonne and J. Schaeken (Eds.) Languages in contact. Amsterdam: Rodopi. pp. 155-178.

Nakagawa, H. 2006. Aspects of the Phonetic and Phonological Structure of the Glui Language. Unpublished PhD thesis, University of the Witwatersrand.

Nienaber, G.S. 1963. Hottentots. Pretoria: Van Schaik.

Nienaber, G.S. 1994. 'Pa-hulle' is kreools. Suid-Afrikaanse Tydskrif vir Taalkunde 21: 14-67. Ponelis, F. 1993. The development of Afrikaans. Frankfurt: Peter Lang.

Van Wyk, G.J., A.E. Cloete, A. Jordaan, H.C. Liebenberg and H.J. Lubbe. 2003. Etimologiewoordeboek van Afrikaans. Stellenbosch: WAT.

Visser, H. 2010. Verbal compounds in Naro. In M. Brenzinger and C. König (Eds.) Khoisan languages and linguistics: Proceedings of the 1st International Symposium January 4-8, 2003, Riezlern/Kleinwalsertal. Vol. 24. Cologne: Rüdiger Köppe Verlag. pp. 176-200.

Buro van die Woordeboek van die Afrikaanse Taal (WAT). Stellenbosch. Selection of electronic data consulted. 